\title{
PRAVNA PRIRODA SUDSKE NAGODBE
}

Dr. sc. Lidija Vojković*

\author{
UDK 347.925 \\ https://doi.org/10.30925/zpfsr.40.2.12 \\ Ur.: 27. kolovoza 2018. \\ Pr.: 8. siječnja 2019. \\ Stručni rad
}

\begin{abstract}
Sažetak
Autorica u radu daje prikaz pravne prirode sudske nagodbe kao posebnog instituta procesnog prava. Kako bi se odredila pravna priroda sudske nagodbe prethodno je nužno odrediti njezin pojam te svojstva koja čine njezinu pravnu prirodu, a to je svojstvo da se njome okončava parnica, svojstvo pravomoćne $i$ ovršne presude $i$ da nije moguća nova parnica o istoj pravnoj stvari. Po pravnoj prirodi sudska se nagodba razlikuje od izvansudske nagodbe kao instituta materijalnoga građanskog prava. Iako pravila procesnoga prava sadrže određene odredbe o sudskoj nagodbi ona tim procesnim pravilima nije u cijelosti uređena, posebno u pogledu pravnih sredstava za njezino pobijanje. Stoga je potrebno pored materijalnopravnih tužbi za pobijanje, predvidjeti $i$ procesnopravno sredstvo slično prijedlogu za ponavljanje postupka. Zbog posebne pravne prirode, sudska nagodba stvara određene procesnopravne učinke po kojima se izjednačava s pravomoćnom i ovršnom sudskom presudom, što je čini posebnim $i$ učinkovitim pravnim sredstvom rješavanja sudskih sporova.
\end{abstract}

Ključne riječi: sudska nagodba; pravna priroda sudske nagodbe; pravomoćnost; ovršnost; ne bis in idem.

\section{1. $U V O D$}

U pravnom prometu sudionici mogu stupati u različite odnose i preuzimati određena prava i obveze koji su po svojoj prirodi građanskopravni odnosi i na njih se primjenjuju pravila građanskoga materijalnog prava. Međutim, ako nastane spor u pogledu preuzetih prava i obveza stranke taj sporni odnos mogu riješiti u postupku pred sudom na koji se primjenjuju pravila procesnoga građanskog prava.

Ako je spor u tijeku ili ga stranke tek namjeravaju pokrenuti one mogu taj sporni odnos prekinuti i riješiti ga sklapanjem sudske nagodbe tijekom parničnog postupka ili prije njegovog pokretanja. Tako sklopljena sudska nagodba otklanja potrebu daljnjeg vođenja postupka i ona postaje pravomoćna te se po procesnim učincima izjednačava s pravomoćnom presudom.

* Dr. sc. Lidija Vojković, sutkinja Županijskog suda u Splitu, lidija.vojkovic@zsst.pravosudje.hr. 
Pravnu prirodu sudske nagodbe određuju njeni procesnopravni učinci $\mathrm{s}$ obzirom na to da je to procesna radnja koja se poduzima u postupku pred sudom koji je strogo formalan postupak što mu daje posebna obilježja. Po pravnoj prirodi razlikuje se sudska nagodba sklopljena u posebnom postupku pred nadležnim sudom od nagodbe sklopljene po pravilima materijalnoga građanskog prava. Sudskom i izvansudskom nagodbom parnične odnosno ugovorne strane međusobno uređuju svoje građanskopravne odnose kojima mogu slobodno raspolagati.

$\mathrm{S}$ obzirom na brzinu i učinkovitost u pravnom prometu građanskopravna nagodba ima važno mjesto dok sudska nagodba ima posebnu pravnu snagu koja proizlazi iz njene pravne prirode jer se sudska nagodba izjednačava s pravomoćnom i ovršnom sudskom presudom. Zbog svojstva pravomoćnosti sudska nagodba dovodi do okončanja postupka i nemogućnosti vođenja nove parnice o istoj pravnoj stvari u kojoj je sklopljena sudska nagodba. Upravo zbog toga pravna priroda sudske nagodbe predmet je ovoga rada.

\section{POJAM SUDSKE NAGODBE}

Kako bismo odredili pojam sudske nagodbe nužno je prethodno prikazati različita shvaćanja pojma sudske nagodbe. Pojam sudske nagodbe, njezina pravna priroda, procesni učinci te pravna sredstva za pobijanje različito se određuju u pravnoj znanosti, u zakonodavstvima i sudskoj praksi. ${ }^{1}$

Sudska nagodba smatra se isključivo materijalnopravnim ugovorom građanskog prava ili se smatra procesnopravnom radnjom za koju ne vrijede pravila materijalnoga građanskog prava. ${ }^{2}$ Jedni autori strogo razgraničavaju sudsku nagodbu od građanskopravne nagodbe, dok drugi shvaćaju sudsku nagodbu kao građanskopravni posao i procesnu radnju, koja se prosuđuje po pravilima materijalnog i procesnog prava. ${ }^{3}$

Sudska je nagodba sporazum koji sve ili samo neke od stranaka ili eventualno treći, na temelju sudskog odobrenja, zaključuju tijekom parničnog (parnična sudska nagodba) ili nekoga drugog sudskog postupka (neparnična sudska nagodba) potpisivanjem sudskog zapisnika u koji je taj sporazum unesen. Time njegovi potpisnici u cijelosti ili djelomično uređuju svoje odnose u vezi s predmetom spora ili

1 Dika, M., Građansko parnično pravo, Sudske odluke i sudska nagodba, IX. knjiga, Zagreb, Narodne novine, 2013., str. 515; Triva, S., Dika, M., Građansko parnično procesno pravo, Narodne novine, Zagreb, 2004., str. 569; Triva, S., Sadržaj sudske nagodbe, Zbornik Pravnog fakulteta u Zagrebu, 2/1960. str. 120; Radanović, M., Sudska nagodba u parničnom postupku i praksi, Naša zakonitost, 5/1969., str. 391; Korlaet, R., Materijalno i procesno značenje nagodbe, Odvjetnik, 7-8/1983., str. 14.

2 Takvo shvaćanje, po kojem je sudska nagodba materijalnopravni ugovor, zastupaju Rosenberg i Neumann. Sudska nagodba je procesnopravna radnja po shvaćanju Sauera i Sperla. Prema Trivi, S., Pravna priroda sudske nagodbe, Zbornik Pravnog fakulteta u Zagrebu, 3-4/1959, str. 213.

3 Razgraničenje između sudske nagodbe kao materijalnopravnog ugovora i procesne radnje vrši Hellwig. Sudska nagodba je mješoviti materijalnopravni i procesnopravni fenomen, po shvaćanju Steina, Schonkea, Pollaka, Zuglije i dr. Prema Trivi, S., Pravna priroda..., str. 214. Vidi i Triva, S., Dika, M., Građansko parnično..., str. 573. 
u povodu njega, a koji može imati učinke pravomoćne sudske odluke te, ako je njime utvrđena i obveza na neku činidbu, i ovršne isprave. ${ }^{4}$

Sudska je nagodba ugovor kojim stranke uređuju svoje građanskopravne odnose kojima mogu slobodno raspolagati, a koji je zaključen u pisanom obliku pred nadležnim sudom i koji je dopustio sud u parničnom ili u izvanparničnom postupku te ima svojstva pravomoćne presude i posebno ovršne isprave, ako se njime ugovara obveza na neku činidbu. ${ }^{5}$

U sudskoj je praksi sudska nagodba mješoviti procesnopravni i građanskopravni ugovor, pa se njezina valjanost prosuđuje i prema građanskom procesnom pravu i prema građanskom materijalnom pravu. ${ }^{6}$ Polazeći od navedenoga, ovlaštenje punomoćnika stranke za sklapanje sudske nagodbe ocjenjuje se po pravilima procesnog prava, $\mathrm{tj}$. odredbi članka 95. Zakona o parničnom postupku (u daljnjemu tekstu: ZPP), ${ }^{7}$ dok su za pravne posljedice nepostojanja tog ovlaštenja mjerodavne odredbe materijalnog prava, tj. odredbe Zakona o obveznim odnosima (u daljnjemu tekstu: ZOO). ${ }^{8}$

Sudska nagodba (res iudicaliter transacta) po svojoj je pravnoj prirodi procesnopravna radnja i građanskopravni ugovor stranaka, kojim one uređuju svoje dispozitivne građanskopravne odnose, tako što je sklapaju u posebnom pisanom obliku pred sudom, što joj daje posebna procesnopravna svojstva, tako da ona proizvodi određene procesnopravne učinke. Sudska se nagodba po određenim procesnim učincima izjednačava $\mathrm{s}$ pravomoćnom sudskom presudom. Ona ima prednosti pred presudom, ponajprije presudom na temelju priznanja i presudom na temelju odricanja, jer je učinkovitije sredstvo zaštite od njih. Sudska nagodba sklopljena u parničnom postupku dovodi do okončanja parnice, a sklopljena u izvanparničnom postupku otklanja potrebu vođenja parnice. Sudska je nagodba procesna smetnja za vođenje postupka, pa tužbu podnesenu o predmetu spora o kojem je sklopljena sudska nagodba treba odbaciti kao nedopuštenu. ZPP ne određuje pojam sudske nagodbe, procesnopravne učinke, niti pravna sredstva za njeno pobijanje. Do njihovog se određenja dolazi posredno, tumačenjem pojedinih odredbi ZPP-a koje uređuju sudsku nagodbu.

Pravna priroda i procesnopravni učinci koje ona stvara ovise o značenju koje se daje sudskoj nagodbi. Sudska nagodba razlikuje se od nagodbe u materijalnopravnom smislu. Nagodba je institut materijalnog građanskog prava i uređena je odredbama članka 150. do 159. ZOO-a. Prema odredbi članka 150. ZOO-a, koja određuje pojam nagodbe, ugovorom o nagodbi osobe između kojih postoji spor ili neizvjesnost o nekom pravnom odnosu, uzajamnih popuštanja, prekidaju spor, odnosno otklanjaju neizvjesnost i određuju svoja uzajamna prava i obveze. Prema odredbi članka 158. stavka 1. ZOO-a nagodba je ništetna ako je zasnovana na pogrešnom vjerovanju oba

4 Dika, M., Građansko parnično..., str. 515.

5 Triva, S., Dika, M., Građansko parnično..., str. 573.

6 Odluka Vrhovnog suda Republike Hrvatske br. Rev 2351/92 od 19. studenoga 1992. Izbor odluka Vrhovnog suda Republike Hrvatske, 1994., br. 1., str. 293.

7 Zakon o parničnom postupku, Narodne novine, br. 154/11 - pročišćeni tekst, 25/13 i 89/14.

8 Zakon o obveznim odnosima, Narodne novine, br. 35/05, 41/08, 125/11, 78/15 i 29/18. Odluka Vrhovnog suda Republike Hrvatske br. Rev $331 / 93$ od 14. travnja 1993. Izbor odluka Vrhovnog suda Republike Hrvatske, 1994., br. 1., str. 295. 
ugovaratelja da postoji pravni odnos koji ustvari ne postoji, i ako bez toga pogrešnog vjerovanja ne bi među njima bilo ni spora ni neizvjesnosti. Isto vrijedi i kada se pogrešno vjerovanje oba ugovaratelja odnosi na činjenice prema članku 158. stavku 2. ZOO-a. Odricanje od ove ništetnosti nema pravnog učinka i ono što je dano na ime ispunjenja obveza iz takve nagodbe može se tražiti natrag prema odredbi članka 158. stavka 3. ZOO-a. Odredbom članka 159. ZOO-a određeno je da odredbe nagodbe čine cjelinu te ako je jedna odredba ništetna, cijela je nagodba ništetna, osim ako se iz nje vidi da se sastoji od neovisnih dijelova.

U ostalim odredbama ZOO određuje u čemu se sastoji uzajamno popuštanje, pretpostavke valjanosti nagodbe, poništaj, ništetnost i pravni učinci nagodbe. ${ }^{9}$

\section{PROCESNE ODREDBE O SUDSKOJ NAGODBI}

Sudska je nagodba institut procesnog prava. U našem pravnom sustavu uređena je odredbama članka 321. do 324. ZPP-a. Prema odredbi članka 321. stavka 1. ZPP-a stranke mogu tijekom cijeloga postupka pred parničnim sudom do njegova pravomoćnog okončanja zaključiti nagodbu o predmetu spora (sudska nagodba), pa i tijekom postupka pred drugostupanjskim sudom do donošenja drugostupanjske odluke u povodu žalbe nagodbu. Nagodba se može odnositi na cijeli tužbeni zahtjev ili na jedan njegov dio prema odredbi članka 321. stavka 2. ZPP-a. Sud će tijekom postupka upozoriti stranke na mogućnost sudske nagodbe i pomoći im da zaključe nagodbu prema odredbi članka 321. stavka 3. ZPP-a. Prema odredbi članka 321. stavka 4. ZPP-a pred sudom se ne može zaključiti nagodba u pogledu zahtjeva kojima stranke ne mogu raspolagati (članak 3. stavak 3. ZPP). Prema odredbi članka 321. stavka 5. ZPP-a kad sud donese rješenje kojim se ne dopušta nagodba stranaka, zastat će s postupkom dok to rješenje ne postane pravomoćno.

Sudsku nagodbu stranke mogu zaključiti pred sudom kojije proveo prvostupanjski postupak, odnosno pred drugostupanjskim sudom ako se održava sjednica vijeća uz sudjelovanje stranaka prema odredbi članka 362. stavka 2. ZPP-a ili rasprava prema

9 Odredbom članka 151. stavka 1. ZOO-a određeno je da se popuštanje može sastojati, među ostalim, u djelomičnom ili potpunom priznavanju nekog zahtjeva druge strane ili u odricanju od nekog svog zahtjeva; u uzimanju na sebe neke nove obveze; u smanjenju kamatne stope; $\mathrm{u}$ produljenju roka; u pristajanju na djelomične uplate, u davanju prava na odustatninu. Prema stavku 3. istoga članka, kad samo jedna strana popusti drugoj, na primjer, prizna pravo druge strane, onda to nije nagodba i ne podliježe pravilima o nagodbi.

Člankom 152. ZOO-a određeno je da je za sklapanje ugovora o nagodbi potrebna sposobnost za raspolaganje pravom koje je sadržaj nagodbe.

Prema članku 153. stavku 1. ZOO-a sadržaj nagodbe može biti svako pravo kojim se može raspolagati. Prema stavku 2. članka 153. ZOO-a valjana je nagodba o imovinskim posljedicama kaznenog djela, a prema stavku 3. ne mogu biti sadržajem nagodbe sporovi koji se tiču statusnih odnosa.

Člankom 154. stavkom 1.ZOO-a za ugovor o nagodbi vrijede opće odredbe o dvostranoobveznim ugovorima, ako za njega nije što drugo predviđeno. Prema stavku 2. članka 154. ZOO-a kad pod nazivom nagodbe ugovaratelji sklope neki drugi pravni posao, na njihove se odnose ne primjenjuju odredbe zakona koje vrijede za nagodbu, već one koje vrijede za stvarno sklopljeni posao. 
odredbi članka 373.b. stavka 2. ZPP-a, kada se nagodba može zaključiti i pred tim sudom u smislu odredbe članka 321. stavka 6. ZPP-a.

Prema odredbi članka 321. stavka 7. ZPP-a ako stranka hoće zaključiti nagodbu pred prvostupanjskim sudom nakon donošenja prvostupanjske odluke dok je postupak u povodu žalbe u tijeku pred drugostupanjskim sudom, prvostupanjski će sud bez odgode zatražiti - telefonom, telefaksom ili elektroničkom poštom, od drugostupanjskog suda da ga se obavijesti o tome je li već odlučeno u povodu žalbe te obavijestiti taj sud da stranke namjeravaju zaključiti sudsku nagodbu. Prvostupanjski sud će strankama dopustiti zaključenje nagodbe nakon što ga drugostupanjski sud obavijesti da još uvijek nije odlučeno u povodu žalbe i da je zastao s postupkom dok se postupak zaključenja nagodbe ne dovrši.

Prema odredbi članka 321. stavka 8. ZPP-a ako stranke zaključe nagodbu nakon donošenja prvostupanjske odluke, a prije donošenja drugostupanjske odluke $u$ povodu žalbe, sud pred kojim je nagodba zaključena rješenjem će ukinuti donesenu prvostupanjsku odluku i utvrditi da je tužba povučena, osim ako stranke nisu drukčije riješile to pitanje u zaključenoj nagodbi.

Sporazum stranaka o nagodbi unosi se u zapisnik (članak 322. stavak 1. ZPP-a). Nagodba je zaključena kad stranke nakon pročitanog zapisnika o nagodbi potpišu zapisnik (članak 322. stavak 2. ZPP-a). Strankama će se na njihov zahtjev izdati ovjeren prijepis zapisnika u koji je unesena nagodba (članak 322. stavak 3. ZPP-a).

Prema odredbi članka 323. ZPP-a sud tijekom cijeloga postupka po službenoj dužnosti pazi vodi li se parnica o predmetu o kojemu je ranije bila zaključena sudska nagodba. Ako utvrdi da se parnica vodi o predmetu o kojemu je već zaključena sudska nagodba, odbacit će tužbu. Osoba koja namjerava podići tužbu može pred nižim prvostupanjskim sudom na čijem području protivna strana ima prebivalište pokušati postići nagodbu. Tada će sud kojem je taj prijedlog podnesen pozvati protivnu stranu i upoznati je s prijedlogom nagodbe sukladno odredbi članka 324. ZPP-a, a troškove tog postupka podmiruje podnositelj prijedloga.

Prema odredbi članka 186.d. stavka 1. ZPP-a sud može tijekom cijeloga parničnog postupka strankama predložiti da spor riješe u postupku mirenja pri sudu ili izvan suda. Ako stranke suglasno predlože ili prihvate spor riješiti mirnim putem pred sudom, bez odgode će se odrediti ročište radi pokušaja mirenja na koje se pozivaju stranke, njihovi zastupnici i opunomoćenici ako ih imaju (članak 186.d. stavak 2. ZPP-a). Prema odredbi članka 186.d. stavak 4. ZPP-a nagodba sklopljena u postupku mirenja provedenom u sudu ima važnost sudske nagodbe.

Sklopljena predstečajna nagodba ima snagu ovršne isprave za sve vjerovnike čije su tražbine utvrđene tom nagodbom. Dospijeće tih tražbina dokazuje se zapisnikom s ročišta za sklapanje predstečajne nagodbe odnosno rješenjem o odobrenju sklapanja predstečajne nagodbe iz članka 9. Zakona o financijskom poslovanju i predstečajnoj nagodbi (Narodne novine, br. 108/12, 144/12, u daljnjemu tekstu: ZFPPN). Predstečajna nagodba je sudska nagodba na što upućuje odredba članka 83. ZFPPN-a, koja za vjerovnike čije su tražbine utvrđene ima snagu ovršne isprave sukladno odredbi članka 66. stavka 12 . ZFPPN-a. ${ }^{10}$

10 Odluka Visokog trgovačkog suda Republike Hrvatske br. Pž-6599/2014 od 12. rujna 2014. 


\section{PRAVNA PRIRODA SUDSKE NAGODBE}

Pravnu prirodu sudske nagodbe određuju procesnopravni učinci koje ona stvara. Sudska nagodba u procesnom smislu proizvodi određene procesnopravne učinke koji ju obilježavaju i čine je različitom od izvansudske, materijalnopravne nagodbe. Sudska nagodba kao procesnopravna radnja i poseban ugovor procesnog prava ima određena posebna obilježja koja je čine sličnom presudi. ${ }^{11}$

Sklopljenom sudskom nagodbom parnične stranke uređuju sporni odnos, što dovodi do okončanja parnice odnosno drugog postupka, a tako sklopljena sudska nagodba izjednačava se u procesnom smislu sa pravomoćnom sudskom presudom. Sudska nagodba ima snagu ovršne isprave.

Ako je u određenoj pravnoj stvari sklopljena sudska nagodba nije dopušteno pokrenuti novu parnicu o istoj pravnoj stvari između istih stranaka. Ako o toj pravnoj stvari bude pokrenuta parnica, tužbu treba odbaciti zbog nedostatka pravnog interesa. Nije dopušteno ponovno odlučivanje o zahtjevu o kojem je sklopljena sudska nagodba jer je to bitna povreda odredbi postupka, pa presudu treba ukinuti i tužbu odbaciti.

Sva ta obilježja određuju pravnu prirodu sudske nagodbe koja će, u daljnjem tekstu, biti pobliže određena.

\subsection{Okončavanje parnice}

Prema odredbi članka 321. ZPP-a, stranke mogu zaključiti sudsku nagodbu o predmetu spora tijekom cijeloga postupka pred parničnim sudom prvog stupnja. Prema odredbi članka 321. stavka 7. ZPP-a, stranka može zaključiti nagodbu pred prvostupanjskim sudom nakon donošenja prvostupanjske odluke, dok je postupak u povodu žalbe u tijeku pred drugostupanjskim sudom, ako drugostupanjski sud još nije odlučio u povodu žalbe.

Sudska nagodba može se zaključiti i prije pokretanja parnice, a isto tako i u izvanparničnom postupku. Zaključenje sudske nagodbe treba dopustiti sve dok se njome može nadomjestiti sudska odluka, tj. do pravomoćnog okončanja parnice. ${ }^{12}$

Sudska nagodba bi se mogla zaključiti u izvanparničnom postupku, prije podnošenja tužbe pred nadležnim prvostupanjskim sudom na čijem području barem jedna od stranaka ima boravište, pred prvostupanjskim parničnim sudom, u stadiju postupanja po žalbi, sve dok se parnica pravomoćno ne okonča, u adhezijskom postupku te pred zamoljenim sudom. ${ }^{13}$ Sudska nagodba dovodi do okončanja parnice i to ne sama izjava stranaka da su sklopile nagodbu, već procesnopravni učinak okončanja parnice nastupa kada stranke potpišu sudski zapisnik u koji je unesen sadržaj nagodbe. $\mathrm{U}$ tom trenutku zaključenja sudska nagodba neposredno i konstitutivno djeluje na

Izbor odluka Vrhovnog suda Republike Hrvatske, 2014., br. 2.; vidjeti i Maganić, A., Pravna sredstva protiv predstečajne nagodbe, Zbornik Pravnog fakulteta u Zagrebu, 3-4/2015., str. 409.

11 Dika, M., op. cit., str. 527; Triva, S., Pravna priroda..., str. 209; Triva, S., Sadržaj..., str. 120; Radanović, M., op. cit., str. 391; Korlaet, R., op. cit., str. 14; Jelinić, S., Pobijanje sudske nagodbe, Odvjetnik, 5-6/1973., str. 211.

12 Triva, S., Dika, M., op. cit., str. 574.

13 Dika, M., op. cit., str. 574. 
okončanje parnice. Tada nikakva druga parnična radnja stranaka nije potrebna, pa ni izjava o povlačenju tužbe, odnosno pristajanju na povlačenje.

Za valjanost i dopuštenost sudske nagodbe te da bi dovela do okončanja parnice moraju biti ispunjene određene pretpostavke. Sudska nagodba treba biti zaključena pred nadležnim prvostupanjskim sudom, u posebnom obliku sudskog zapisnika. Parnične stranke koje je sklapaju trebaju imati pravni interes i sposobnost, odnosno procesno ovlaštenje za njeno sklapanje. Predmet i sadržaj sudske nagodbe moraju biti dopušteni. Sudska nagodba se može zaključiti samo u okviru onih pravnih odnosa kojima stranke mogu slobodno raspolagati, te mora biti u skladu s prisilnim propisima i pravilima morala.

Sudska nagodba nije dopuštena u statusnim sporovima, u kojima stranke ne mogu raspolagati svojim zahtjevima. ${ }^{14}$ Raspolaganja stranaka koja su u suprotnosti s prisilnim propisima i pravilima javnog morala, sud neće uvažiti, te će donijeti rješenje kojim ne dopušta sudsku nagodbu.

Ako je sudska nagodba zaključena u parničnom postupku ona dovodi do okončanja parnice, a sudska nagodba zaključena u izvanparničnom postupku otklanja potrebu vođenja parnice. S obzirom da sudska nagodba dovodi do okončanja parnice ne može se ponovno voditi parnica o onoj pravnoj stvari u kojoj je sklopljena sudska nagodba. Ukoliko je u istoj pravnoj stvari podnesena tužba nju treba odbaciti kao nedopuštenu.

\subsection{Pravomoćnost}

Sudska nagodba nije sudska odluka već procesnopravna radnja i građanskopravni ugovor stranaka, koja se sklapa u posebnom obliku pred sudom što određuje njenu pravnu prirodu, daje joj poseban procesnopravni karakter i posebna svojstva. Sudske odluke su presuda i rješenje. Sudska odluka je i rješenje kojim se ne dopušta sudska nagodba. Zbog svoje pravne prirode sudska nagodba se, u određenim aspektima, u procesnopravnom smislu izjednačava s pravomoćnom sudskom presudom. ${ }^{15}$

Svojstvo pravomoćnosti sudske nagodbe nije izričito određeno odredbama ZPP-a već se o njemu zaključuje posredno, tumačenjem pojedinih odredbi o sudskoj nagodbi. Po svojoj pravnoj prirodi sudska nagodba već time što je na valjan način zaključena dovodi do pravomoćnog okončanja parnice. Sudska nagodba postaje pravomoćna u trenutku zaključenja, odnosno kad je parnične stranke potpišu, i po pravomoćnosti se u procesnopravnom smislu izjednačava s pravomoćnom sudskom presudom. Tražbina utvrđena sudskom nagodbom zastarijeva za deset godina isto kao i tražbina utvrđena pravomoćnom sudskom presudom prema odredbi članka 333. stavka 1. ZOO-a.

Po pravnoj prirodi sudska nagodba može biti kondemnatorna, konstitutivna i deklaratorna. Sudska nagodba je kondemnatorna kada se njome ugovara obveza na neko činjenje, trpljenje ili propuštanje. Izvršenje obveza iz sudske nagodbe može se

14 Međutim, odredbama članka 331. do 341. Obiteljskog zakona, Narodne novine, br. 103/15, uređena je obiteljska medijacija kao postupak u kojem stranke nastoje sporazumno riješiti spor iz obiteljskih odnosa s pomoću jednog ili više obiteljskih medijatora.

15 Vidjeti Dika, M., O biti i granicama pravomoćnosti, Zagreb, Sveučilišna naklada, 1991. 
ugovoriti na različite načine i u različitim rokovima, nasuprot strogim paricijskim rokovima kod presude. Konstitutivnom sudskom nagodbom se stvaraju novi pravni odnosi, preinačavaju ili ukidaju postojeći pravni odnosi. Deklaratornom sudskom nagodbom utvrđuje se postojanje odnosno nepostojanje nekog prava ili pravnog odnosa, te istinitost odnosno neistinitost neke isprave. ${ }^{16}$

Presuda postaje pravomoćna kada se više ne može pobijati žalbom, odnosno kad žalba bude pravomoćno odbijena ili odbačena, dok je sudska nagodba pravomoćna kada, nakon što stranke potpišu sudski zapisnik u koji je unesen sadržaj nagodbe, sudac taj zapisnik strankama pročita i ovjeri.

O pravnoj stvari o kojoj je sklopljena sudska nagodba ne može se voditi nova parnica, isto kao i kod pravomoćne sudske presude. Tako se prigovor rei iudicaliter transactae izjednačava s prigovorom rei iudicatae. Na sudsku nagodbu se, kao i na pravomoćnu presudu, odnosi i primjenjuje pravilo ne bis in idem. Ovakvo shvaćanje o sudskoj nagodbi zastupljeno je u našem pravnom sustavu i ono proizlazi iz odredbi parničnog procesnog prava. Polazeći od toga sud tijekom cijeloga postupka, sukladno odredbi članka 323. ZPP-a, po službenoj dužnosti pazi vodi li se parnica o predmetu u kojem je ranije bila sklopljena sudska nagodba. Ukoliko sud utvrdi da se parnica vodi o predmetu o kojem je već sklopljena sudska nagodba, tužbu će odbaciti. Sudska nagodba je procesna smetnja za vođenje istovjetne parnice među istim strankama, te je sudac ovlašten tužbu odbaciti, u stadiju prethodnog ispitivanja tužbe, kao i na pripremnom ročištu sukladno odredbi članka 288. stavka 2. ZPP-a, sve do okončanja postupka.

Pravna priroda pravomoćnosti sudske nagodbe, po kojoj se ona izjednačuje s pravomoćnom sudskom presudom, ogleda se i u odredbama o apsolutno bitnim povredama odredaba parničnog postupka. Uvijek postoji bitna povreda odredaba parničnog postupka ako je odlučeno o zahtjevu o kojem je sklopljena sudska nagodba, prema odredbi članka 354. stavka 2. točke 9. ZPP-a. Drugostupanjski sud je tada dužan po službenoj dužnosti ukinuti presudu i tužbu odbaciti, pozivom na odredbu članka 369. stavka 2. u svezi s člankom 366. stavkom 1. ZPP-a. Isto će postupiti Vrhovni sud Republike Hrvatske kada odlučuje o izjavljenoj reviziji, sukladno odredbi članka 385. stavka 1. točke 1. ZPP-a.

Zbog toga što se sudskoj nagodbi daje isto značenje kao i pravomoćnoj presudi i zbog toga nije dopušteno o onoj pravnoj stvari o kojoj je sklopljena sudska nagodba voditi novu parnicu. Tada stranka nema pravni interes za donošenje presude, pa tužbu, u istoj pravnoj svari u kojoj je sklopljena sudska nagodba treba odbaciti. ${ }^{17}$ Ako nagodba ne bi imala značenje pravomoćne presude, odnosno značenje presuđene stvari, postojao bi pravni interes za donošenje presude nakon sklopljene sudske nagodbe jer bi presuda u tom slučaju pružala potpuniju zaštitu. Međutim, dok teče parnica stranke mogu, o predmetu spora, izvan suda sklopiti nagodbu. Izvansudska nagodba nema neposredni procesnopravni učinak na parnicu, niti zbog toga stranke gube pravni interes za vođenje parnice i pravnu zaštitu. Izvansudska nagodba, odnosno prigovor rei transactae u parnici, ne dovodi do odbacivanja tužbe već do prihvaćanja

16 Dika, M., Građansko str. 527.

17 ibid. str. 545; Jelinić, S., op. cit., str. 213. 
ili odbijanja tužbenog zahtjeva.

\subsection{Ovršnost}

Sudska presuda, a isto tako i sudska nagodba da bi imale snagu ovršne isprave prethodno trebaju imati svojstvo pravomoćnosti. Pravomoćnost je pretpostavka ovršnosti presude i sudske nagodbe. Za sklapanje i za stjecanje tog svojstva nije potreban nikakav rok, već samo potpisivanje sudskog zapisnika, odnosno njegova ovjera dovodi do pravomoćnog okončanja postupka.

Da bi se mogla ostvariti tražbina koja je njom određena sudska nagodba mora imati svojstvo ovršne isprave. Ovršnost je svojstvo ovršne isprave da se tražbina koja je u njoj određena može prisilno, putem suda ostvariti. Sudska nagodba ima pravnu snagu ovršne isprave i to njeno svojstvo određeno je izričito odredbom članka 23. stavka 1. točke 1 . Ovršnog zakona (u daljnjemu tekstu: OZ) ${ }^{18}$ prema kojem su, između ostalog, ovršne isprave ovršna sudska odluka i ovršna sudska nagodba. Prema odredbi članka 24. stavka 1. OZ-a sudskom nagodbom smatra se nagodba sklopljena u postupku pred sudom i pred izbranim sudom. Sudska odluka je ovršna ako je postala pravomoćna i ako je protekao rok za dobrovoljno ispunjenje tražbine koja je u njoj određena.

Sudska, odnosno upravna nagodba je ovršna ako je tražbina koju prema njoj treba ispuniti dospjela. Dospijeće tražbine dokazuje se zapisnikom o nagodbi ili javnom ispravom ili po zakonu ovjerovljenom ispravom prema odredbama članka 27. stavka 1. i 2. OZ-a. Nagodba sklopljena pred sudom, neovisno o tome je li sklopljena u parničnom postupku, prije nego je parnica počela teći ili u izvanparničnom postupku, prema odredbama ovršnog postupka predstavlja ovršnu ispravu.

Sve pravomoćne presude i sudske nagodbe nemaju snagu ovršne isprave. Svojstvo ovršne isprave imaju samo one sudske nagodbe koje su po svojoj prirodi kondemnatorne, tj. one kojima se ugovara obveza na neko davanje, činjenje, trpljenje ili propuštanje. ${ }^{19}$ Ovršne isprave nisu, niti mogu postati sudske nagodbe, a isto tako ni sudske presude, deklaratornog i konstitutivnog karaktera. ${ }^{20}$ Sudska nagodba se i po ovom svojstvu ovršne isprave izjednačuje s pravomoćnom presudom.

U odnosu na presudu, a posebno presudu na temelju priznanja i presudu na temelju odricanja, sudska nagodba ima određene prednosti. Sudskom nagodbom se mogu brže urediti pravni odnosi među strankama, te odrediti rokovi izvršenja činidbi kako to odgovara ugovornim strankama neovisno o zakonskim rokovima za presudu. Zbog toga je sudska nagodba elastičnije i učinkovitije procesno sredstvo od presude.

\subsection{Ne bis in idem}

S obzirom da se sudska nagodba po svom svojstvu pravomoćnosti izjednačava s pravomoćnom sudskom presudom to otklanja potrebu vođenja nove parnice o istoj pravnoj stvari u kojoj je sklopljena sudska nagodba zbog nedostatka pravnog interesa

18 Ovršni zakon, Narodne novine, br. 112/12, 25/13, 93/14, 55/16 i 73/17.

19 Dika, M., Građansko..., str. 553; Triva, S., Pravna priroda..., str. 218.

20 loc. cit.; Jelinić, S., op. cit., str. 217. 
- ne bis in idem. Zbog toga tužbu podnesenu o predmetu spora u kojem je sklopljena sudska nagodba treba odbaciti kao nedopuštenu. Ako je odlučeno o pravnoj stvari u kojoj je sklopljena sudska nagodba to je bitna povreda odredbi postupka, pa presudu treba ukinuti i tužbu odbaciti.

Pravomoćna sudska presuda može se pobijati izvanrednim pravnim lijekovima, pa tako i prijedlogom za ponavljanje postupka, dok takva mogućnost ne postoji kod sudske nagodbe. ZPP u odredbama o ponavljanju postupka ne predviđa mogućnost pobijanja sudske nagodbe prijedlogom za ponavljanje postupka.

ZPP ne predviđa izričito procesna sredstva kojima bi se mogla pobijati sudska nagodba zbog nedostataka procesnih i materijalnopravnih pretpostavki za njenu valjanost. Prema stajalištu sudske prakse sudska nagodba ne može se pobijati prijedlogom za ponavljanje postupka, već samo tužbom. ${ }^{21}$

Ako je ugovorne stranke koje su sklopile sudsku nagodbu žele zbog određenih razloga pobijati, stoje im na raspolaganju redovne građanske tužbe, predviđene odredbama materijalnoga građanskog prava, tj. odredbama ZOO-a. Sudska nagodba se, tako, može pobijati tužbom radi utvrđenja ništetnosti sudske nagodbe, tužbom radi poništenja nagodbe te tužbom radi proglašenja nedopuštenosti ovrhe određene na temelju sudske nagodbe. Parnice pokrenute ovim tužbama nisu parnice o istoj pravnoj stvari o kojoj je sklopljena sudska nagodba te se na njih ne odnosi pravilo o nedopuštenosti vođenja nove parnice.

Predmet spora i pobijanja u tom je slučaju pravomoćna sudska nagodba. Sredstva za pobijanje sudske nagodbe su materijalnopravnoga karaktera. Postoje li pretpostavke za poništenje sudske nagodbe prosuđuje se po pravilima materijalnoga građanskog prava, a također i pravilima procesnog prava, ovisno o razlogu zbog kojeg se sudska nagodba poništava. ${ }^{22}$

Kada se radi o procesnim razlozima mogućnost pobijanja sudske nagodbe trebala bi se ograničiti na one procesne razloge zbog kojih bi se pravomoćne presude na temelju priznanja i na temelju odricanja mogle pobijati prijedlogom za ponavljanje postupka. Ako su u pitanju materijalnopravni razlozi sudska nagodba bi se mogla pobijati tužbom zbog mana volje, bitnih procesnih nedostataka te zbog onih materijalnopravnih razloga zbog kojih se i inače može pobijati izvansudska nagodba dok bi se tužbom moglo tražiti utvrđenje ništetnosti sudske nagodbe iz razloga zbog kojih se to može tražiti kad je u pitanju izvansudska nagodba. U hrvatskom pravu nedostaju odredbe kojima bi se uredili razlozi za pobijanje sudske nagodbe kao što su uređeni razlozi za pobijanje presude na temelju priznanja i presude na temelju odricanja, sredstva za pobijanje, pretpostavke i rokovi za njihovo korištenje. U tom se pravcu predlaže mogućnost pobijanja sudske nagodbe prijedlogom za ponavljanje postupka zbog razloga zbog kojih se može pobijati presuda na temelju priznanja i

21 Odluka Vrhovnog suda Republike Hrvatske, br. Rev 331/93 od 14. travnja 1993. Izbor odluka Vs RH 1994., br. 1., str. 294.; Jelinić, S., op. cit., str. 216.

22 Prema odluci Vrhovnog suda Republike Hrvatske, br. Rev br. 1174/85 od 28. 11. 1985. kada je sadržaj sudske nagodbe nedopušten, sud može u povodu zahtjeva stranke utvrditi njezinu ništetnost, ali nije ovlašten mijenjati njen sadržaj. Grbin, I., Zakon o parničnom postupku sa sudskom praksom, bilješkama, napomenama i prilozima, Zagreb, 2000., str. 239; Bazala, B., Sudska nagodba može se pobijati samo tužbom, Odvjetnik, 9/1959., str. 195. 
presuda na temelju odricanja. ${ }^{23}$

Odredbom članka 421. stavka 3. ZPP-a je, između ostalog, predviđeno da se postupak pravomoćno završen presudom na temelju priznanja i presudom na temelju odricanja može ponoviti zato što je izjava o priznanju, odnosno odricanju dana $u$ bitnoj zabludi ili pod utjecajem prisile ili prijevare.

Prema odredbi članka 65. stavka 1. točke 4. OZ-a ovrha se može odgoditi i u povodu tužbe za pobijanje sudske nagodbe, dok se prema odredbi članka 72. stavka 1. OZ-a ovrha određena na temelju sudske nagodbe može obustaviti tek nakon što se ona poništi ili utvrdi njena nedjelotvornost.

Teoretski bi postojala mogućnost izmjene sadržaja sudske nagodbe zbog promijenjenih okolnosti, koje su nastupile nakon sklapanja sudske nagodbe. ${ }^{24}$ Procesne odredbe članka 342. i 347. ZPP-a, o ispravku presude i rješenja kao sudskih odluka, odnose se isključivo na mogućnost ispravka presude i rješenja, a nikako i na mogućnost ispravka sudske nagodbe bez obzira na to je li sklopljena tijekom ili prije parnice. $^{25}$

\section{ZAKLJUČAK}

Po pravnoj prirodi sudska nagodba je specifičan institut procesnog prava koja procesna pravila sadrži u odredbama ZPP-a.

Sudska nagodba poseban je građanskopravni ugovor i parnična radnja stranaka, kojim one, u strogo formalnom postupku pred sudom, uređuju svoje međusobne odnose, kojima mogu slobodno raspolagati tako da ona stvara određene procesnopravne učinke po kojima se razlikuje od izvansudske nagodbe.

Pravnu prirodu i procesnopravne učinke sudske nagodbe određuje to što: sudska nagodba dovodi do okončanja parnice, ona stječe svojstvo pravomoćnosti, ima snagu ovršne isprave te nedopuštenost vođenja nove parnice o istoj pravnoj stvari u kojoj je sklopljena sudska nagodba.

Zbog toga se valjanost sudske nagodbe prosuđuje prema pravilima građanskoga procesnog prava i prema pravilima građanskoga materijalnoga prava.

$\mathrm{S}$ obzirom na to odredbe procesnog prava ne uređuju pravna sredstva za pobijanje sudske nagodbe kao niti rokove za njeno pobijanje u sudskoj praksi je zauzeto stajalište da se sudska nagodba može pobijati samo tužbama te bi de lege lata trebalo ostati kod takvog stajališta u sudskoj praksi i tužbu radi poništaja, tužbu radi utvrđenja ništetnosti sudske nagodbe i tužbu radi stavljanja izvan snage sudske nagodbe smatrati pravnim sredstvima za pobijanje sudske nagodbe.

Međutim, kako je sudska nagodba institutu procesnog prava, de lege ferenda, pravno sredstvo za pobijanje sudske nagodbe bi trebalo biti ono koje bi trebalo urediti odredbama procesnog prava, a koje bi bilo slično prijedlogu za ponavljanje postupka kojim bi se moglo tražiti ukidanje sudske nagodbe zbog razloga zbog kojih bi se moglo tražiti pobijanje presude na temelju priznanja i presude na temelju odricanja

23 Dika, M., Građansko..., str. 546.

24 Osibov, I., Sudska nagodba i promijenjene okolnosti, Naša zakonitost, 4/1981., str. 65.

25 Izbor odluka Vrhovnog suda Republike Hrvatske, 1998., br. 1, str. 172. 
zbog razloga zbog kojih se one mogu pobijati i u rokovima sličnim onima određenim za njihovo pobijanje.

\section{Knjige i članci:}

\section{LITERATURA}

1. Bazala, Branko, Sudska nagodba može se pobijati samo tužbom, Odvjetnik, 9/1959. vol. 9, str. 195-201.

2. Dika, Mihajlo, Građansko parnično pravo, Sudske odluke i sudska nagodba, IX. knjiga, Zagreb, Narodne novine, 2013.

3. Dika, Mihajlo, O biti i granicama pravomoćnosti, Zagreb, Sveučilišna naklada, 1991.

4. Grbin, Ivo, Zakon o parničnom postupku sa sudskom praksom, bilješkama, napomenama i prilozima, Zagreb, Organizator, 2000.

5. Jelinić, Srećko, Pobijanje sudske nagodbe, Zagreb, Odvjetnik, 5-6/1973. vol. 46; str. 211218.

6. Korlaet, Radoje, Materijalno i procesno značenje nagodbe, Zagreb, Odvjetnik, 7-8/1983. vol. 56, str. 14-20.

7. Maganić, Aleksandra, Pravna sredstva protiv predstečajne nagodbe, Zbornik Pravnog fakulteta u Zagrebu, 3-4/2015., str. 409-437.

8. Osibov, Ivo, Sudska nagodba i promijenjene okolnosti, Naša zakonitost, vol. 35, 4/1981., str. 65-79.

9. Radanović, Mile, Sudska nagodba u parničnom postupku i praksi, Naša zakonitost, vol. 23, 5/1969., str. 391-399.

10. Triva, Siniša, Dika, Mihajlo, Građansko parnično procesno pravo, Narodne novine, Zagreb, 2004.

11. Triva, Siniša, Pravna priroda sudske nagodbe, Zbornik Pravnog fakulteta u Zagrebu, vol. 9, 3-4/1959., str. 209-220.

12. Triva, Siniša, Sadržaj sudske nagodbe, Zbornik Pravnog fakulteta u Zagrebu, vol. 10, 2/1960., str. 120-127.

Sudska praksa:

1. Izbor odluka Vrhovnog suda Republike Hrvatske, 2014., br.2.

2. Izbor odluka Vrhovnog suda Republike Hrvatske, 1998., br. 1.

3. Izbor odluka Vrhovnog suda Republike Hrvatske, 1994., br. 1.

\section{Propisi:}

1. Obiteljski zakon, Narodne novine, br. 103/15.

2. Ovršni zakon, Narodne novine, br. 112/12, 25/13, 93/14, 55/16 i 73/17.

3. Zakon o financijskom poslovanju i predstečajnoj nagodbi, Narodne novine, br. 108/12 i $144 / 12$.

4. Zakon o obveznim odnosima, Narodne novine, br. 35/05, 41/08, 125/11, 78/15 i 29/18.

5. Zakon o parničnom postupku, Narodne novine, br. 154/11 - pročišćeni tekst, 25/13 i $89 / 14$. 


\section{Lidija Vojković*}

\section{Summary \\ THE LEGAL NATURE OF SETTLEMENT}

The paper describes the legal nature of settlement as a special institute of procedural law. In order to establish the legal nature of settlement, we must first define its concept and characteristics, whereby the latter encompass the fact that a settlement brings an end to the proceedings, that it produces the effects of a final and enforceable court ruling, and that continued litigation of the same matter is not possible. We have to differentiate between a settlement and an out-of-court settlement as an institute of civil substantive law. Although the rules of procedural law do contain certain provisions on settlement, they do not regulate the matter completely, especially in terms of the remedies for challenging such decisions. Therefore, there is a need for envisaging procedural remedies that are similar to the renewal of proceedings. Due to its special legal nature a settlement produces certain procedural effects, due to which it is comparable to a final and enforceable court ruling. A settlement is thus a special and effective legal remedy for dispute resolution.

Keywords: settlement; legal nature of settlement; finality; enforceability; ne bis in idem.

Zussamenfassung

\section{DIE RECHTSNATUR DES GERICHTLICHEN VERGLEICHS}

Dieser Beitrag stellt die Rechtsnatur des gerichtlichen Vergleichs als Sonderinstituts des Prozessrechts dar. Um die Rechtsnatur des gerichtlichen Vergleichs zu bestimmen, muss man zuerst dessen Begriff und Eigenschaften bestimmen. Kennzeichnend für den gerichtlichen Vergleich ist, dass dadurch ein Prozess beendet wird, dass der Vergleich rechtskräftig und vollstreckbar ist und dass ein neuer Prozess über die gleiche Rechtssache nicht möglich ist. Der Rechtsnatur nach unterscheidet sich der gerichtliche Vergleich vom außergerichtlichen Vergleich als Institut des materiellen Zivilrechtes. Obwohl manche Bestimmungen über den gerichtlichen Vergleich in den Regeln des Prozessrechts enthalten sind, ist er durch diese Prozessregeln nicht ganz geregelt, insbesondere bezüglich der Rechtsmittel für dessen Anfechtung, weshalb es notwendig ist, neben der materiellrechtlichen

* Lidija Vojković, Ph.D., judge at the County Court of Split, lidija.vojkovic@zsst.pravosudje.hr. 
Klagen für dessen Anfechtung auch prozessrechtliche Mittel, ähnlich dem Antrag auf Erneuerung des Verfahrens, vorzusehen. Wegen seiner besonderen Rechtsnatur erzeugt der gerichtliche Vergleich bestimmte prozessrechtliche Wirkungen, weswegen man behaupten kann, dass der gerichtliche Vergleich und das rechtskräftige und vollstreckbare Urteil gleich sind. Aus diesem Grund ist der gerichtliche Vergleich ein besonderes und effektives Rechtsmittel für die Beilegung von Rechtsstreitigkeiten.

Schlüsselwörter:gerichtlicher Vergleich; Rechtsnatur des gerichtlichen Vergleichs; Rechtskräftigkeit; Vollstreckbarkeit; ne bis in idem.

\section{Riassunto}

\section{LA NATURA GIURIDICA DELLA TRANSAZIONE GIUDIZIALE}

Nel presente lavoro l'autrice illustra la natura giuridica della transazione giudiziale quale fattispecie del diritto processuale. Al fine di determinare la natura giuridica della transazione giudiziale occorre in primo luogo accertarne la nozione, come anche le caratteristiche costitutive e cioè che si tratti di una transazione con la quale si termina una lite; che abbia le caratteristiche di una sentenza definitiva di condanna in forza della quale non sia possibile intentare una nuova lite sullo stesso oggetto. In base alla sua natura giuridica, la transazione giudiziale si distingue dalla transazione stragiudiziale quale istituto giuridico del diritto privato sostanziale. Benché le regole del diritto processuale contengano certune disposizioni sulla transazione giudiziale, essa non è regolata per intero in ispecie con riguardo ai mezzi giuridici volti ad invalidarla. In tale senso è pertanto necessario affiancare alla domanda di diritto sostanziale volta all'invalidità anche uno strumento di diritto processuale simile alla richiesta di rinnovo del procedimento. A causa della particolare natura giuridica la transazione giudiziale sortisce determinati effetti processuali in base ai quali essa si assimila alla sentenza di condanna definitiva, il che la rende un mezzo particolare ed efficace nella risoluzione di liti giudiziali.

Parole chiave: transazione giudiziale; natura giuridica della transazione giudiziale; passaggio in giudicato; esecutività; ne bis in idem. 


\section{Prikazi}

(Book Reviews, Beschprechungen, Prezentazioni) 
